\title{
Relative importance of family, site, and field placement timing on survival, growth, and yield of hatchery-produced Pacific oyster spat (Crassostrea gigas)
}

\author{
Lionel Dégremont ${ }^{\mathrm{a}}$, Edouard Bédier ${ }^{\mathrm{a}, \mathrm{b}}$, Patrick Soletchnik ${ }^{\mathrm{c}}$, Michel Ropert ${ }^{\mathrm{d}}$, Arnaud Huvet ${ }^{\mathrm{e}}$, \\ Jeanne Moal $^{\mathrm{e}}$, Jean-Francois Samain ${ }^{\mathrm{e}}$ and Pierre Boudry ${ }^{\mathrm{a},{ }^{*}}$
}

\footnotetext{
aIFREMER - Laboratoire de Génétique et Pathologie - 17390 La Tremblade, France

'IFREMER - Laboratoire Conchylicole de Bretagne - 56470 La Trinité, France

IFREMER - Laboratoire Environnement Ressources de Poitou-Charentes - 17390 La Tremblade, France

dIFREMER - Laboratoire Environnement Ressources de Normandie - 14520 Port en Bessin, France

IFREMER - Unité Mixte de Recherche Physiologie et Ecophysiologie des Mollusques Marins, Ifremer, Centre de Brest, B.P. 70, 29280 Plouzané, France
}

*: Corresponding author : Tel.: +33 5467626 30; fax: +33 5467626 11.; email : pierre.boudry@ifremer.fr

\begin{abstract}
:
Summer mortality has been reported in the Pacific oyster, Crassostrea gigas, for many years in different parts of the world. The causes of this phenomenon are complex. The multidisciplinary program "MOREST", coordinated by IFREMER, was initiated to understand the causes of summer mortality of Crassostrea gigas juveniles in France and to reduce its impact on oyster production. Within this program, three successive groups of bi-parental families were bred in a hatchery in 2001 and placed in the field during summer in three sites (Ronce, Rivière d'Auray, and Baie des Veys). This paper reports the relative importance of family, site and field placement timing for three characters of major importance for oyster production: survival, growth, and yield. At the end of the summer period, significant differences for the three characters were observed among sites and families for each group. Family effect was the largest variance component for survival, representing $46 \%$ of the total. Variance component analysis revealed that variation in yield among families depended either on survival or on growth according to the site. Significant family $\times$ environment interactions were observed for yield and survival but not for growth. No difference in survival was found among groups in the three sites at the end of the experiment, but a critical period of mortality was identified from late July until early September. The influence of environmental conditions, notably on reproductive allocation and its relationship with the studied traits, is discussed.
\end{abstract}

Keywords: Survival; Growth; Yield; Oysters; Crassostrea gigas; Juvenile 


\section{Introduction}

The Pacific oyster, Crassostrea gigas, is the most important commercial oyster species cultivated in the world, with a production estimated at 4.2 million tons in 2001 (FAO, 2003). As with many farmed species, growth and survival are the most important traits because of their direct relationship with yield and therefore the profitability of production. The combined study of growth and survival is essential to understand their variation and the resulting yield. For example, when competition for food and/or space is a limiting factor, the impact of mortality on yield can be compensated by subsequent better growth of survivors. However, most previous studies have investigated these traits separately.

The main factors responsible for growth variability in oysters are food availability, temperature and salinity (Héral and Deslous-Paoli, 1991; Mann et al., 1991). Growth rate is very variable among individuals of the same age reared under common conditions (Galtsoff, 1964 ; Haley and Newkirk, 1977 ; Zouros et al., 1980 ; Jarayabhand and Newkirk, 1989 ; Collet et al., 1999; Boudry et al., 2003). Certain stocks may be better adapted to their habitat conditions than others (Brown and Hartwick, 1988; Héral and Deslous-Paoli, 1991; Soletchnik et al., 2002) and heritable variation has been reported for growth (e.g. Nell et al., 1996, 1999; for review see Sheridan, 1997; Ernande et al., 2004).

Survival is also very important for commercial oyster production (Sindermann, 1976). Large scale oyster mortality events have been reported in many of the main production areas, and the economic implications of these mortalities are often serious. Some mortality events have been attributed to epizooties caused by infectious agents (e.g. Le Roux et al., 2002), but many remain of 'unknown origin' despite intensive scientific investigations. This is the case of "summer mortality" affecting C. gigas.

Summer mortality, which touches both juveniles and adults (Maurer et al., 1986; Cheney et al., 2000) and diploids as well as triploids (Calvo et al., 1999; Cheney et al., 2000), is one of the major problems affecting the production of $C$. gigas. The first case was reported as early as 1915, in Japan (Takeuchi et al., 1960). Similar large-scale mortalities were first recorded in the U.S.A during the late 1950s (Glude, 1975), and during the early 1980s in France (Maurer and Comps, 1986), where episodes of mortality generally occurred in spring for adults and in summer for juveniles (Fleury et al., 2001). Considered together, these studies indicate that, in most cases, summer mortalities cannot be explained by a single factor but rather by the combination of environmental (biotic and abiotic) and internal (genetic, physiological and immunological) parameters. Firstly, considering environmental influences, it is known that mortality can occur when water temperature and salinity are abnormally elevated (Koganezawa, 1975; Ventilla, 1984). Secondly the internal influence of reproduction has been reported by several authors, mortality being interpreted as the result of physiological and/or metabolic disturbance, sometimes associated with the over-maturation of the gonads (Tamate et al., 1965; Maurer and Comps, 1986). Thirdly, pathogens have been associated with some cases of summer mortality (Imai et al., 1968; Elston et al., 1987; Friedmann et al., 1991, Waechter et al., 2002; Le Roux et al., 2002), but in many other cases no clear association was found (e.g. Bodoy et al., 1990). Finally, different susceptibilities of C. gigas, among stocks of different origins or among different hatchery-bred families, have been reported (Beattie et al., 1980; Hershberger et al., 1984; Soletchnik et al., 2002; Ernande et al., 2004), indicating genetic variability for the ability to resist the summer mortality phenomenon.

A national multidisciplinary program ("MOREST") was initiated in France in 2001 to investigate the causes of the summer mortalities in Crassostrea gigas juveniles. Within this program, a multi-site field experiment was designed to assess the performance of hatchery spat during the summer period in terms of survival, growth and yield. In the present paper, 
we report the study of the relative effect of site, timing of placement in the field on survival, growth and yield of bi-parental families of $C$. gigas.

\section{Material and methods}

\subsection{Broodstock conditioning and spawning}

In November 2000, 300 oysters were collected from the wild in the Marennes-Oleron Bay, placed in the IFREMER hatchery in La Tremblade (France) and randomly divided into three groups, which were subsequently used in crosses made in February, March and April to produce the three successive 'groups'. These broodstock oysters were placed in 120-1 conditioning raceways with a flow of $400 \mathrm{l} \mathrm{h}^{-1}$. The sea water temperature was gradually increased to $21^{\circ} \mathrm{C}$ over an 8-day period, and oysters were then held at $21^{\circ} \mathrm{C}$ throughout a 60 day conditioning period. A cultured phytoplankton diet (Isochrysis galbana, Chaetoceros pumilum, Tetraselmis suecica, Pavlova lutheri and Skeletonema costatum) was added continuously to the sea water to favor gametogenesis.

After this conditioning period, the broodstock oysters were sexed, and 6 males and 24 females were randomly selected for the production of each group. Spermatozoids of the males and oocytes of the females were collected from each individual by stripping the gonad. Each sire was mated with 4 different dams, producing 24 full-sib families as described in Ernande et al. (2003). This was repeated 3 times, February $5^{\text {th }}$, March $5^{\text {th }}$ and April $18^{\text {th }} 2001$, producing 3 successive groups of families and giving 72 full-sib families in all.

\subsection{Larval and spat culture}

Each family was reared as described in Ernande et al. (2003). Briefly, larvae were reared in $30-\mathrm{l}$ tanks at $23^{\circ} \mathrm{C}$ in filtered sea water which was changed 3 times per week. The larvae were fed daily with a mixed diet of cultured phytoplankton (Isochrysis galbana, Chaetoceros pumilum, Pavlova lutheri and Tetraselmis suecica). Eyed larvae were settled on cultch in raceways and reared under standard hatchery conditions. During this period, water flow, food ration and temperature were controlled, and when spat reached $2 \mathrm{~mm}$, they were transferred to the IFREMER nursery in Bouin (France) in March $22^{\text {th }}$, April $19^{\text {th }}$ and May $30^{\text {th }}$ 2001 respectively for groups 1, 2 and 3 . The nursing period lasted 2 to 3 months, the oysters were then put out in the field in bags $(7 \mathrm{~mm}$ mesh size, $100 \times 27 \mathrm{~cm})$. Due to differential survival at the larval and settlement stages (see Boudry et al., 2002; Ernande et al., 2003) and limited facilities in the nursery, only 14 (for group 1) to 15 (for groups 2 and 3) families per group were monitored in the field. Overall, 44 families were placed in the field at each site. Before placement in the field, 200 oysters per family were individually weighed.

\subsection{Growout and sampling protocol}

Growth, survival and yield of oysters were monitored in three sites on the coasts of France (Fig. 1) : Ronce in the Marennes-Oléron Bay $\left(1^{\circ} 10^{\prime} \mathrm{W}, 45^{\circ} 48^{\prime} \mathrm{N}\right)$, Rivière d'Auray in Brittany ( $\left.2^{\circ} 57^{\prime} \mathrm{W}, 44^{\circ} 45^{\prime} \mathrm{N}\right)$ and Baie des Veys in Normandy $\left(1^{\circ} 06^{\prime} \mathrm{W}, 49^{\circ} 23^{\prime} \mathrm{N}\right)$. Oysters were cultured following usual local practices, off-bottom, using iron frames ('tables') onto which the oyster bags are attached. Groups were put out in the three sites on June $20^{\text {th }}$ for group 1, July $5^{\text {th }}$ for group 2 and August $7^{\text {th }}$ for group 3 (Fig. 2). Each family was represented by 9 bags of 150 oysters each at each site and the total weight of each bag was recorded. These bags were randomly distributed on the tables. Oysters were sampled 15 (P1) and 30 (P2) days after placement in the field (3 bags per sampling date per family) (Fig. 2). Because 
mortality and growth are known to be usually very low in France in late autumn (DeslousPaoli and Héral, 1988; Soletchnik et al., 1999), a common final sampling (P3) of 3 bags was performed for all groups in October $2^{\text {nd }}$. As a result, oysters were reared in the field during 104, 89 and 56 days for groups 1, 2 and 3 respectively. Survival (number of live animals at sample/150) and total weight of live oysters were recorded each date. Additionally, individual weight was recorded for 30 to 90 oysters per family at P2 and P3.

Water temperature was monitored at all sites during the study period using YSI probes (four records per hour).

\subsection{Statistical analyses}

Percentage survival (S) and individual weight (Ps) were respectively arcsine square root and log transformed before statistical analysis in order to increase the normality of the data and the homogeneity of variance (Neter et al., 1985). The daily yield (Yd) was defined as follows:

Yd $=100 \times$ (Wts-Wti) / (Wti x dps)

Where Wts = total weight of live spat at the different sampling dates P1, P2 or P3; Wti = initial total weight of live spat at $\mathrm{P} 0$, and dps = number of days in the field.

ANOVA models from the SAS ${ }^{\circledR}$ software package were used to analyze $\mathrm{S}$ and $\mathrm{Yd}$, following the procedure GLM (SAS Institute Inc., 1989). For Ps, taking into account that oysters were not individually tagged, and that individual weight was recorded at 29, 33 and 28 days for P2 and 104, 89 and 56 for P3 respectively for groups 1, 2 and 3, growth (i.e. gain in total weight over time) was analyzed by ANCOVA on the individual weight with the time in the field as a continuous variable (PROC GLM, SAS Institute Inc., 1989). The TEST option of the RANDOM statement was used to define the appropriate F-statistics for each model due to nested effects and interaction effects (Littell et al., 2002), and multiple comparison tests were used to determine differences in means by the Tukey method (LSMEANS).

Variance components for S and Yd for the three sampling dates were determined using PROC VARCOMP with the restricted maximum likelihood method. For Ps at P2 and P3, data was transformed using the following formula before being submitted to this statistical analysis:

$\mathrm{Pc}=\log (\mathrm{Ps}) / \mathrm{dps}$

Where $\mathrm{Pc}=$ the individual weight transformed, $\mathrm{Ps}=$ the individual weight, $\mathrm{dps}=$ the number of days in the field. Log transformation was used in order to increase normality of the data.

The models used to determine the variance components were:

Survival and yield:

$\mathrm{Y}_{i j k l m}=\mu+$ group $_{i}+$ site $_{j}+$ family $_{k(i)}+$ replicate $_{l(k i)}+\operatorname{group}_{i} \mathrm{x}_{\text {site }_{j}}+$ site $_{j} \mathrm{x}_{\text {family }_{k(i)}}+\mathrm{E}_{i j k l m}$

Where $\mathrm{Y}_{\mathrm{ijklm}}=$ survival or yield of the $m$ spat in the $l$ replicate within the $k$ family within the $i$ group in the $j$ site; $\mu=$ overall mean $;$ group $_{i}=$ group effect $(i=1,2,3)$; $\operatorname{site}_{j}=$ site effect $(j=$ Ronce, Rivière d'Auray , Baie des Veys); family ${ }_{k(i)}=$ family effect $(k=1, \ldots, 44)$ within

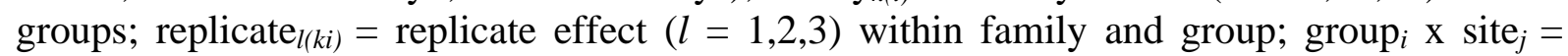
group-site interaction effects; site $_{j} \mathrm{x}$ family $_{k(i)}=$ site-family interaction effects within group; and $\mathrm{E}_{i j k l m}=$ observation error. All the effects were random.

Individual weight: 
$\mathrm{Y}_{i j k l}=\mu+$ group $_{i}+$ site $_{j}+$ family $_{k(i)}+$ group $_{i} \mathrm{x}_{\text {site }_{j}}+$ site $_{j} \mathrm{x}$ family $_{k(i)}+\mathrm{E}_{i j k l}$

Where $\mathrm{Y}_{i j k l}=$ individual weight of the $l$ spat in the $k$ family within the $i$ group in the $j$ site; $\mu=$ overall mean $;$ group $_{i}=$ group effect on individual weight $(i=1,2,3)$; site $_{j}=$ site effect $(j=$ Ronce, Rivière d'Auray , Baie des Veys); family ${ }_{k(i)}=$ family effect $(k=1, \ldots, 44)$ within

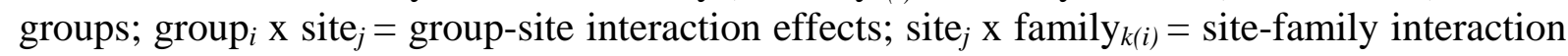
effects within group; and $E_{i j k l}=$ observation error. All the effects were random.

For each group and site, Pearson correlation coefficients between growth, survival and daily yield were determined by PROC CORR and multiple regressions were performed by PROC REG (SAS Institute Inc., 1995) to determine the survival and growth contributions to daily yield after the summer period (P3). The same analysis was made overall groups at each site.

\section{Results}

\subsection{Water temperature}

Figure 2 presents the seawater temperatures at the three sites over the experimental period. Mean seawater temperatures over the summer were $18.3^{\circ} \mathrm{C}$ in Baie des Veys, $19.7^{\circ} \mathrm{C}$ in Rivière d'Auray and $20.1^{\circ} \mathrm{C}$ in Ronce. After a month and a half in the field, mean temperatures of the seawater were higher for group 3 than for group 1 in all three sites because they corresponded to a later period in the year. Temperature also differed among sites. At the beginning of group 1, water temperature was below $18^{\circ} \mathrm{C}$ in Bay des Veys, while it was around $20^{\circ} \mathrm{C}$ at the other sites during the same period (Figure 2).

\subsection{Survival}

Family, site and family x site interaction all had significant effects on survival at the three sampling dates, although replicate (i.e. bag) effect was not significant. Variance component analysis at P3, the final sampling common to all groups, indicated that family, site and their interaction represented $80.9 \%$ of the total variance observed for survival. The variance components for survival are shown in Table 1., and the means, standard deviations and significance tests at the different levels in Table 2.

Family effect accounted for 33.9, 45.1 and $46.4 \%$ of the total of variance respectively for groups 1, 2 and 3 (Table 1). Within sites and groups, a significant difference in survival among families was observed for group 1 at P1 and P3 in Ronce, and at P2 and P3 in Rivière d'Auray $(\mathrm{p}<0.01)$, but no significant difference was found in Baie des Veys (Table 2). For the two other groups, significant differences of survival among families were found at almost all sites and sampling dates, except in Baie des Veys at P3 for group 2 and in Rivière d'Auray at $\mathrm{P} 1$ for group 3.

The group and site effects were significant and together represented about $20 \%$ of the total variance at each sampling date while interactions between site and family represented about $12 \%$. At the end of the summer period, mean survival was $93.6 \%$ in Baie des Veys, 84.3\% in Ronce and 75.5\% in Rivière d'Auray.

Within group, survival was significantly different among sites for all sampling dates, except for group 1 at P1. In group 1, survival was very high in all three sites two weeks after placement in the field (P1), and ranged from $97.5 \%$ to $99.3 \%$ indicating a good acclimation to field conditions. After one month in the field (P2), survival decreased significantly in Rivière d'Auray (89.1\%), while it remained high (> 97\%) in the two other sites. In October, survival 
was still high in Baie des Veys (94.4\%), but lower in Rivière d'Auray (75.6\%) and in Ronce (88.7\%) (Table 2). In group 2, survival was good and had a similar level in Ronce and Rivière d'Auray at P1 (91.8\% and 85.7\%) and P2 (85.7 and 87.2\%) but was significantly better in Baie des Veys at both points (P1: 96.5\% and P2: 95.6\%). In group 3, survival decreased earlier in Ronce (88.5\% at P1), than in Rivière d'Auray (94.8\% at P1). In Baie des Veys, survival was high $(>93 \%)$ for the three sampling dates. The ranking of survival performance among sites was different among groups and sampling dates except for P3, i.e. significant site $\mathrm{x}$ group interactions were apparent at P1 and P2 (Table 1).

Considering all groups within site, survival was significantly different among groups at P1 in the three sites and at P2 in Ronce and Baie des Veys (Table 2). Thus, group 1 showed the best survival performances overall whereas in the other two groups, the ranking was different among sites depending upon sampling date. No significant difference was observed among groups at P2 in Rivière d'Auray or in all sites at P3 (Table 2). This explains the significant interaction found between site and group at P1 and P2 (Table 1).

\subsection{Individual weight and growth}

Variance components of individual weight differed markedly from those of survival (Table 3). Site and group components became greater than family over the experimental period and were higher than they had been for survival (Tables 1 and 3). The mean individual mean weight of spat at the end of the hatchery period (P0) and in the three field sites (at P2 and P3) is presented in Table 4.

The site and group components for individual weight both increased between P2 and P3, from 4.0 to $25.3 \%$ and from 0 to $22.5 \%$ respectively (Table 3 ). Family variance component (within each group) was much lower for individual weight (11.6\% at P2 and $4.5 \%$ at P3) than it had been for survival. Interactions between family and site were low and not significant (representing only $1.5 \%$ of the total variance at P3). For all sites and all groups, analysis of covariance showed significant differences in growth for all effects except the group effect between P0 and P2 and the interaction between site and family between P0-P3 (Table 3).

At P0, although a significant difference in individual weight was observed among families in each group, there were no significant differences in individual mean weight among groups, which remained within the range 1.65 to $1.70 \mathrm{~g}$. Within group and site at both field sampling dates (P2 and P3), significant differences in weight attained were also observed among families except for the group 2 in Rivière d'Auray at P3 (Table 4).

After one month in the field (P2), a significant difference in growth was observed among sites, with the highest growth in Ronce and Baie des Veys whilst the oysters placed at Rivière d'Auray grew less (Table 4). At the end of the summer period, significant growth differences were found among groups and among sites (Table 4). Relative to the time spent in the field, the best growth was observed in group 3 while group 1 showed the least growth. The latest placed group therefore grew the best. Comparing sites, oysters reared in Baie des Veys had the highest growth, and those at Rivière d'Auray the lowest (Table 4).

A significant difference in growth was found among sites for each group at P2 and P3 (Table 4). For group 1, individual mean weight in the three sites ranged from 3.80 to 4.73g at P2, and from 11.17 to 19.63g at P3. Growth in Baie des Veys and Ronce was similar and significantly higher than in Rivière d'Auray at the two sampling dates. For groups 2 at P2, there was better growth at Ronce than in the two other sites, where growth was similar. For group 3 at P2, growth was significantly different among the three sites with the best growth in Baie des Veys and the lowest in Rivière d'Auray. At P3, oysters showed significantly better 
growth in Baie des Veys than in Ronce and in Ronce than in Rivière d'Auray in groups 2 and 3.

Considering groups within site, the growth comparison among groups indicated no significant difference in Ronce and Rivière d'Auray at P2 whereas a significant difference among groups was observed in Baie des Veys with better growth for group 3 in comparison with groups 1 and 2 (Table 4). At P3 (i.e. after 104, 89 and 56 days in the field for groups 1, 2 and 3 respectively), a significant difference in growth was observed among groups in Baie des Veys and in Ronce with better growth for group 3 once more compared to group 2 and group 1 , where growth was significantly lower.

\subsection{Yield}

Comparing variance components for yield (Table 1) we see that site effect accounted for $9 \%$ of total variance at P1 and this increased to $57.3 \%$ by P3. At P1 and P2, the largest component, excluding error, was family which explained $24 \%$ and $29.8 \%$ of the total variance respectively. By October (P3) though, this effect decreased and represented only $15.1 \%$.

The yield of oysters for each group at each site, among groups and among sites for the three sampling dates, together with the significance tests for differences in survival at the different levels, are presented in Table 5. Within groups and sites, no significant difference among families was observed at P1 in Rivière d'Auray, or at P2 in Ronce and Baie des Veys for group 1 (Table 5). In group 2, significant differences among families were found for the three sites and the three sampling dates except in Baie des Veys at P3. For group 3, no significant difference in yield among families was found in Rivière d'Auray or in Baie des Veys at P1.

Over all groups and all sites, analysis of variance showed that all effects were significant except replicate at P1 and P3, group at P2 and the interaction between group and site at $\mathrm{P} 3$ (Table 1). Mean daily yields ranged from 1.43 to $3.03 \%$ among groups at P1, from 3.28 to $4.09 \%$ at P2, and from 3.95 to $6.02 \%$ at P3. Group 1 showed significantly higher yield than the two other groups. Group 2 had a significantly lower yield than group 3 at P1 whereas this was the other way round in October. Mean daily yields per site ranged from 1.89 to $3.02 \%$ at $\mathrm{P} 1$, from 2.32 to $4.77 \%$ at $\mathrm{P} 2$, and from 2.76 to $7.28 \%$ at $\mathrm{P} 3$. Oysters reared in Baie des Veys showed the best daily yields for the 3 sampling dates. Between the other two sites, the oysters showed the same performances at P1 whereas at P2 and P3, those reared in Ronce had better daily yields compared to families reared in Rivière d'Auray.

Site had a significant effect on yield at P1, P2 and P3 for all three groups (Table 1). At the end of the summer period, families reared in Baie des Veys showed a better daily yield than those reared in the two other sites for each group (from 6.38 to 8.04\%) (Table 5). Conversely, families in Rivière d'Auray showed the lowest daily yield for each group compared with those in Ronce and Baie des Veys (from 1.83 to 3.54\%). Effect of group on daily yield was significant at the three sampling dates for all sites, except at P1 in Ronce. At P3, the best daily yields were observed for group 1 whereas group 3 showed the lowest daily yields in all sites.

\subsection{Relationships between growth, survival and yield}

Correlations between growth and survival were not consistent between sites and groups (data not shown). These correlations were positive except for group 2 in Baie des Veys $(r=-0.36, p<0.05)$. Taking all groups together, growth and survival were significantly positively correlated in Ronce $(r=0.41)$ but not in the two other sites. 
After the summer period, growth and survival explained more than $95 \%$ of the daily yield variability for the three groups in the three sites (Fig. 3). In Ronce and Rivière d'Auray, survival was the most important independent variable explaining yield and ranged from $50 \%$ to $92 \%$. In contrast, it was growth which accounted for $92 \%$ and $86 \%$ for groups 1 and 2 respectively in Baie des Veys. Over all groups, survival was the most important parameter in Rivière d'Auray, explaining 65\% of the yield variability whereas growth was more important in Baie des Veys at 78\%. For the third site (Ronce), growth and survival had similar levels of influence on yield variability, with $49 \%$ and $50 \%$ respectively.

\section{Discussion}

\subsection{Survival}

First, it should be noted that after two weeks in the field in Baie des Veys, the most distant site from the nursery, survival was very high for all three groups indicating that any stress incurred from transportation and handling did not lead to mortality higher than $4 \%$ in any group. Consequently, we can deduce that the mortality observed in our study is due to other factors.

Our results showed a very large variation in survival rate among families and among sites, ranging from 99 to $17 \%$. Large variability in survival among families was previously observed by Beattie et al. (1980) and Perdue et al. (1981). These results show that family is the most important effect explaining the variability of survival, which suggests a significant genetic basis for this trait as recently observed in another case study on one year old C. gigas (Ernande et al., 2004). More information about the heritability of early spat survival is needed to determine if selective breeding could efficiently improve this trait (Dégremont, 2003).

The effect of field placement date on spat mortality has rarely been studied. GarciaEsquivel et al. (2000), comparing a spring and a summer batch of C. gigas oyster larvae, did not observe significant differences in terms of survival in the field after the summer period (most mortality occurred in the first month after settlement). The same result was observed for $C$. virginica with the most mortality occurring 3 to 6.5 weeks after placement in the field (Bricelj et al., 1992). In our experiment it is not possible to distinguish between the effect of spat age (from 100 to 130 days old when placed in the field) and the date of field placement (from June $20^{\text {th }}$ to August $7^{\text {th }}$ ). However, no significant differences in survival were observed among groups in October in the three experimental sites which confirm the observations of these two previous studies. Variance components indicate that group effect does not explain the variation observed for survival (Table 1). It is unlikely that mortality which affects hatchery spat between its production in February and April, and the date of transfer to the field influences the mortality recorded after the summer period for juvenile oysters under a year old. An important question about summer mortality was whether an earlier or a later transfer to the field would allow a better acclimation of the spat to field conditions or, alternatively, might avoid the critical mortality period (depending on the timing of mortality in the field). For group 1, significant mortalities were observed after July $20^{\text {th }}$. These were later for groups 2 and 3, between August $4^{\text {th }}$ and $22^{\text {nd }}$ and after August $22^{\text {nd }}$ respectively. Consequently the critical period seems to have started in early August and lasted until early September. Putting hatchery produced spat in the field after this critical period would obviously reduce mortality. 
Variation of survival among sites has frequently been observed in bivalves: Mytilus edulis (Freeman et Dickie, 1979; Dickie et al., 1984), Ostrea angasi (Mitchell et al., 2000), Saccostrea commercialis (Hand et al., 1998) and Crassostrea gigas (Garcia-Esquivel et al., 2000 ; Fleury et al., 2001). For the Pacific oyster, estuarine sites usually lead to higher mortality compared to other coastal sites (Glude, 1975 ; Maurer et al, 1986). Environmental conditions could explain differences in mortality rates observed in the three sites due to physiological effects. High temperatures are associated with summer mortality in the Pacific oyster (Ventilla, 1984; Goulletquer et al., 1998). In the framework of the MOREST project, Moal et al. (2003) and Soletchnick et al. (2003) identified $19^{\circ} \mathrm{C}$ as a threshold temperature for C. gigas summer mortality, associated with reproduction. Gametogenesis has been often reported for oysters less than one year old (Coe, 1931; Galtsoff, 1961; Joseph and Madhyastha, 1984; Dinamani, 1987; Morton, 1990). Coe (1932) also showed a bigger proportion of mature oysters in areas with higher seawater temperatures. In our study, it is possible that a larger proportion of juvenile oysters became mature in Ronce and Rivière d'Auray due to the higher seawater temperature compared to oysters in Baie des Veys (Fig. 2 ). High energetic cost associated with early reproduction when temperature is high could then lead to higher mortality rates, such as those observed in our estuarine sites (Rivière d'Auray and in Ronce).

One interesting point was to know if the timing of mortalities was different among sites as seen in some previous studies (Glude, 1975 ; Perdue et al., 1981 ; Cheney et al, 2000), or if they were simultaneous as was seen elsewhere (Maurer et al., 1986). In our study, the critical period seemed to have been different among sites according to the group. For example, group 2 showed mortality at the same period in Rivière d'Auray, and in Ronce, while group 1 exhibited mortality earlier in Rivière d'Auray than in Ronce. Similarly, differences in the timing of mortalities were observed among families within each group and each site. For example, for group 1 in Rivière d'Auray, some of the families suffered significant mortalities between P1 and P2 while this occurred later in other families (i.e. between $\mathrm{P} 2$ and $\mathrm{P} 3$ ). This illustrates the difficulty in predicting the timing of mortality events and shows that summer mortality of juvenile oysters is the result of a complex interaction between the oysters and their environment.

\subsection{Growth}

Growth rate is known to be greatest during the first year of an oyster's life and then to decrease (Berthome et al., 1986; Shafee and Sabatie, 1986; Mitchell et al., 2000). Brown and Hartwick (1988), comparing spat in British Colombia (Canada), observed growth rates ranging from 34 to $120 \%$ for one-year-old spat and from 163 to $298 \%$ for younger spat. Consequently, young spat is likely to be a good material to study growth variation in oysters.

Oysters were put out in the field when they reached the size of $7 \mathrm{~mm}$. Consequently, no difference in weight was found among groups at P0 and age effect can be considered as null for the interpretation of growth performances. The group effect was therefore represented by the date of placement in the field. In Baie des Veys after one month in the field, the juvenile oysters put out in August grew better than those put out in June and July. In Ronce and Rivière d'Auray, no difference in growth was observed among groups at P2 despite the large difference in their placement date (from June $20^{\text {th }}$ to August $7^{\text {th }}$ ). Growth of farmed oysters is known to be influenced by many environmental parameters: temperature and food availability (Héral, 1991) and immersion time in the case of tidal sites (Héral and Deslous-Paoli, 1991). Our results at P2 suggest that environmental conditions were similar in the period June $20^{\text {th }}$ to September $4^{\text {th }}$ in the two estuarine sites, and different environmental conditions between the period from June $20^{\text {th }}$ to August $7^{\text {th }}$ and the period from August $7^{\text {th }}$ and 
September $4^{\text {th }}$ in Baie des Veys. However, mean temperatures in the three sites were the highest for group 3, intermediate for the group 2 and the lowest for the group 1 in all sites (Figure 2). In the same way, mean Chlorophyll A concentration varied during the summer period in the three sites (Ifremer, 'REPHY QUADRIGE' data base). For example, in 2001, concentration of Chlorophyll a was greater in August $\left(14 \mathrm{mg} \cdot \mathrm{m}^{-3}\right)$ than in June and July (8 mg.m ${ }^{-3}$ ) in Ronce (Faury et al., 2002).

As environmental conditions changed among groups during the first month in the field in each site, suggesting a better growth for oysters deployed in August compared with those placed in June and July, that is in keeping with results observed in Baie des Veys, a first hypothesis which could explain similar growth in Ronce and Rivière d'Auray involves summer mortality. Bricelj et al. (1992) observed a decrease of the growth rate in C. virginica juveniles during mortality events. The high mortality observed in Ronce and Rivière d'Auray at P2 in group 3, and to a lesser extent in group 2, compared with group 1 could have indirectly decreased the growth rate. A second hypothesis concerns reproduction, if different allocations of energy between gonad and soma occurred among groups in Rivière d'Auray and Ronce. More energy was probably allocated to reproduction in groups 3 and 2 compared to group 1 and this could explain the lower growth rate for these later two groups.

At the end of summer period, no significant difference in mortality among groups was observed in the three sites. Consequently, mortality can not account for growth differences between groups in Ronce and Baie des Veys as suggested above. Our favored hypothesis to explain the different growth performances among groups at P3 involves the environmental conditions (seawater temperature, and food availability) and the reproductive allocation. Growth performance observed in Ronce and Baie des Veys suggest that energy allocation between somatic and germinal compartments could be differ with field placement timing within these two sites. Thus, the later the transfer to the field, the less the environmental conditions allowed gametogenesis, due to the decrease in temperature from the end of August (Fig. 2). Consequently, more energy could be allocated to the somatic compartment for juvenile oysters transferred later, resulting in better growth than in juveniles placed at the beginning of summer. In Rivière d'Auray, similar growth among groups would seem to result from a more complex interaction between the oyster and environment.

In bivalves, growth performance is known to vary a great deal between sites. For example, Sparks and Chew (1959) observed growth ranging from 39 to $116 \%$ of the initial size among three growing sites in Washington State, USA. In our study, mean individual growth after one month in the field (P2) varied from $128 \%$ to $216 \%$ of the initial size according to the site and group, and from $209 \%$ to $1075 \%$ at the end of the growing period (P3). At P2, despite the fact that all factors (except group) and interactions between factors were significant, most of the variation was observed within the tested factors or was due to other factors, as indicated by the large contribution (77.1\%) of the error component in the variance analysis. At P3, apart from the error component, site was the most important factor (the best site being Baie des Veys and the worst Rivière d'Auray). This might be related to a different energy allocation between somatic and reproductive compartments among sites for each group due to environmental conditions. Berthelin et al. (2000) showed that the lower temperature in Baie des Veys induces a lower gametogenesis in C. gigas compared to Marennes-Oléron Bay. In October 2001, Lambert et al. (2003) observed, from six selected families in group 2, that oysters reared in Baie des Veys still contained gametes in the gonad whereas in Ronce and Rivière d'Auray they were empty. These authors suggested that oysters in Baie des Veys can redirect resources from non-spawned gametes into growth, which would explain why the best growth was observed in this site. The growth difference between Ronce and Rivière d'Auray at P3 can not only be explained by temperature due to similar values (Fig. 2), but it could be due to their trophic conditions. During the growout 
experiment, chlorophyll A concentration was higher at Ronce, ranging from 8 to $14 \mathrm{mg} \mathrm{m}^{-3}$ (Faury et al., 2002) than Rivière d'Auray where it never exceeded $1.5 \mathrm{mg} \mathrm{m}^{-3}$ (Allenou et al., 2002). Food availability and temperature combined with reproductive development could explain the growth performances observed in the three experimental sites for each group.

\subsection{Yield and its correlation with growth and survival}

Yield is the result of both survival and growth. The combined effect of variation in growth and survival are often difficult to predict, as it is dependent on density and food (or space) availability. High mortality is likely to decrease yield, as the number of live animals becomes the limiting factor. Conversely, when local competition for food or space is great (i.e. when food availability is low), mortality can lead to increased yield because of the lower resulting density and the subsequent increased growth of the surviving oysters. Furthermore, there is a trade-off between growth and survival in one year old oysters, which is related to a shift in resource allocation as recently demonstrated by Ernande et al. (2004). As the level of food availability may vary among sites and/or among years, contrasting correlations can be observed between survival, growth and yield. For example, Foyle et al. (1997) observed a strong positive correlation among sites between growth and survival in the giant clam Tridacna squamosa in 1993 but a significantly negative correlation the following year. Our results showed that correlations between growth, survival and yield varied greatly. These observations are in agreement with the results recently published by Langdon et al. (2003), where significant genotype $\mathrm{x}$ environment interactions were found indicating a large variability for yield among families and among sites. For example in Baie des Veys, mortality was low in group $2(6.8 \%)$ and thus yield variation depended mainly on growth (Fig.3). In Rivière d'Auray, the main factor controlling yield variation among families was survival, as mortality reached $23.5 \%$ by the end of summer period. In all, our study revealed that survival is the most important parameter in the explanation of yield variation, in accordance with previous results found on Mytilus edulis (Freeman and Dickie, 1979). In our case, if mortality was less than 5\%, survival explained less than $10 \%$ of yield variation, but in the range $5-25 \%$ mortality, $10-90 \%$ of yield variation was explained by survival. Above $20 \%$ mortality, more than $90 \%$ of yield variation could be explained in this way.

\section{Conclusion}

Our study on variation of survival, growth and yield in hatchery-produced spat of $C$. gigas in France opens several paths for the improvement of this important phase of the production cycle. First, it shows that the largest amount of variation in survival is observed among families. This suggests a significant genetic component for the trait as proposed by Beattie et al. (1980) and Perdue et al. (1981), and, more recently, by Langdon et al. (2003) and Ernande et al. (2004). Significant variation also exists among sites, but the timing of placement in the field (during the summer period) is less important.

Secondly, growth variation appears to be more under environmental influence than due to a genetic component. Correlations between growth and survival vary among sites and groups, and summer mortality is unlikely to explain the variation in growth. The differences in reproduction allocation, related to environmental conditions of the sites (Berthelin et al., 2000 ; Lambert et al., 2003), could be the main factor explaining growth variation.

Finally, although the relative dependence of yield variation on survival or growth was different according to the site, mortality appears be the principal explanation for yield variation. 


\section{Acknowledgements}

The authors wish to thank the IFREMER hatchery team in La Tremblade and the nursery team in Bouin for technical assistance during the larval and post-larval rearing and, more specially, Pascal Phelipot, Serge Heurtebise and Max Nourry. This work could not have been completed without the participation of many people in the management of the oysters in the field, and the monitoring of their performances. We greatly thank the IFREMER coastal laboratory teams, and particularly Jean-Pierre Joly and Aimé Langlade, Jean Luc Seugnet, Florence Cornette and Charlotte Simonne. We thank Helen McCombie for help with the English in this paper.

\section{References}

Allenou, J.P., Camus, P., Bouget, J.F., Joly, J.P., 2002. Schéma de mise en valeur de la mer Golfe du Morbihan : Etude de l'état trophique du Golfe du Morbihan et croissance des huîtres creuses. Rapport Ifremer, La Trinité sur Mer, France. 69 pp.

Beattie, J.H., Chew, K.K., Hershberger, W.K., 1980. Differential survival of selected strains of Pacific oysters (Crassostrea gigas) during summer mortality. Proc. Natl. Shellfish. Ass. 70, 184-189.

Berthelin, C., Kellner, K., Mathieu, M., 2000. Storage metabolism in the Pacific oyster (Crassostrea gigas) in relation to summer mortalities and reproductive cycle (West Coast of France). Comp. Biochem. Phys. B. 125, 359-369.

Berthome, J.P., Prou, J., Bodoy, A., 1986. Performances de croissance de l'huître creuse, Crassostrea gigas (Thunberg) dans le bassin d'élevage de Marennes-Oléron entre 1979 et 1982. Haliotis 15, 183-192.

Bodoy, A., Garnier, J., Razet, D., Geairon, P., 1990. Mass mortalities of oysters (Crassostrea gigas) during spring 1988 in the bay of Marennes-Oléron, related to environmental conditions. Int. Coun. Explor. Sea, Shellfish Committee, CM 1990 / K. 11, 1-23.

Boudry, P., Collet, B., Cornette, F., Hervouet, V., Bonhomme, F., 2002. High variance in reproductive success of the Pacific oyster (Crassostrea gigas, Thunberg) revealed by microsatellite-based parentage analysis of multifactorial crosses. Aquaculture 204, 283-296.

Boudry, P., Collet, B., McCombie, H., Ernande, B., Morand, B., Heurtebise, S., Gérard, A., 2003. Individual growth variation and its relationship with survival in juvenile Pacific oysters, Crassostrea gigas (Thunberg). Aquac. Int. 11, 429-448.

Bricelj, V.M., Ford, S.E., Borrero, F.J., Perkins, F.O., Rivara, G., Hillman, R.E., Elston, R.A., Chang, J., 1992. Unexplained mortalities of hatchery-reared, juvenile oysters Crassostrea virginica (Gmelin). J. Shellfish Res. 11 (2), 331-347.

Brown, J.R., Hartwick, E.B., 1998. Influences of temperature, salinity and available food upon suspended culture of the Pacific oyster, Crassostrea gigas. I.Absolute and allometric growth. Aquaculture 70, 231-251.

Calvo, G.W., Luckenbach, M.W., Allen, S.K., Burreson, E.M., 1999. Comparative field study of Crassostrea gigas (Thunberg, 1793) and Crassostrea virginica (Gmelin, 1791) in relation to salinity in Virginia. J. Shellfish Res. 18 (2), 465-473.

Cheney, D.P., MacDonald, B.F., Elston, R.A., 2000. Summer mortality of pacific oysters, Crassostrea gigas (Thunberg) : Initial findings on multiple environmental stressors in Puget Sound, Washington, 1998. J. Shellfish Res. 19, 353-359.

Coe, W.R., 1931. Development of the organs and the sequence of the sexual phases in the California oyster (Ostrea lurida). Bull. Shellfish 3, 119-139

Coe, W.R., 1932. Sexual phases in the American oyster (Ostrea virginica). Biol. Bull. 63, 419-441. 
Collet, B., Boudry, P., Thebault, A., Heurtebise, S., Morand; B., Gerard, A., 1999. Relationship between pre- and post-metamorphic growth in the Pacific oyster Crassostrea gigas (Thunberg). Aquaculture 175, 215-226.

Dégremont, L., 2003. Etude des bases génétiques des mortalités estivales et relatoin avec la croissance chez les juvéniles de Crassostrea gigas. Thèse de Doctorat de l’Université de Caen, France. 333 pp.

Deslous-Paoli, J.M., Héral, M., 1988. Biochemical composition and energy value of Crassostrea gigas (Thunberg) cultured in the bay of Marennes-Oléron. Aquat. Living Resour. 1, 239-249.

Dickie, L.M., Boudreau, P.R., Freeman, K.R., 1984. Influences of stock and site on growth and mortality in the blue mussel (Mytilus edulis). Can. J. Fish. Aquat. Sci. 41, 134-140.

Dinamani, P., 1987. Gametogenic patterns in populations of Pacific oyster, Crassostrea gigas, in Northland, New Zealand. Aquaculture 64, 65-76.

Elston, R.A., Beattie, J.H, Friedman, C.S., Hedrick, R.P., Kent, M.L., 1987. Pathology and significance of fatal inflammatory bacteraemia in the Pacific oyster, Crassostrea gigas Thunberg. J. Fish Dis. 10, 121-132.

Elston, R.A., Frelier, P., Cheney, D., 1999. Extrapallial abscesses associated with chronic bacterial infections in the intensively cultured juvenile Pacific oyster Crassostrea gigas. Dis. Aquatic Org. 37, 115-120.

Ernande, B., Clobert, J., McCombie, H., Boudry, P., 2003. Genetic polymorphism and tradeoffs in the early life-history strategy of the Pacific oyster, Crassostrea gigas (Thunberg, 1795): a quantitative genetic study. J. Evol. Biol. 16, 399-414.

Ernande, B., Boudry, P., Clobert, J., Haure, J., 2004. Plasticity in resource allocation based life history traits in the Pacific oyster, Crassostrea gigas. I Spatial variation in fund abundance. J. Evol. Biol. 17: 342-356.

FAO, 2003. Aquaculture production: Quantities 1950-2001. Fishstat Plus. http://www.fao.org/fi/statist/fisoft/FISHPLUS.asp\#Download

Faury, N., Geairon, P., Guilpain, P., 2002. Hydrologie du bassin de Marennes-Oléron. Base de données «RAZLEC ». Année 2001. Rapport interne Ifremer, DRV/RA/LCPC, France. 19 pp.

Fleury, P.G., Goyard, E., Mazurie, J., Claude, S., Bouget, J.F., Langlade, A., Le Coguic, Y., 2001. The assessing of Pacific oyster (Crassostrea gigas) rearing performances by the IFREMER/REMORA network: method and first results (1993-98) in Brittany (France). Hydrobiologia 465 (1-3), 195-208.

Freeman, K.R., Dickie L.M., 1979. Growth and mortality of the blue mussel (Mytilus edulis) in relation to environmental indexing. J. Fish. Res. Board Can. 36, 1238-1249.

Friedman, C.S., Beattie, J.H., Elston, R.A., Hedrick, R.P., 1991. Investigation of the relationship between the presence of a Gram-positive bacterial infection and summer mortality of the Pacific oyster, Crassostrea gigas Thunberg. Aquaculture 94, 1-15.

Galtsoff, P.S., 1961. Physiology of reproduction in molluscs. Am. Zoologist. 1, 273-289.

Galtsoff, P.S., 1964. The American oyster, Crassostrea virginica Gmelin. Fish. Bull. U.S. 64, $1-480$.

García-Esquivel, Z., González-Gómez, M.A., Gómez-Togo, D.L., Galindo-Bect, M.S., Hernandez-Ayon, M., 2000. Microgeographic differences in growth, mortality, and biochemical composition of cultured pacific oysters (Crassostrea gigas) from San Quitin Bay, Mexico. J. Shellfish Res. 19 (2), 789-797.

Glude, J.B., 1975. A summary report of Pacific coast oyster mortality investigations 19651972. 1-28. In : Proceedings of the Third U.S.-Japan Meeting on Aquaculture, Tokyo, Japan. October 15-16, 1974, pp. 1-28. 
Goulletquer, P., Soletchnik, P., Le Moine, O., Razet, D., Geairon, P., Faury, N., Taillade, S., 1998. Summer mortality of the Pacific cupped oyster Crassostrea gigas in the Bay of Marennes-Oléron (France). Cons. int. Explor. Mer, CM 1998 / CC 14, 20 pp.

Haley, L.E., Newkirk, G.F., 1977. Selecting oysters for faster growth. In : Proceedings of the 8 annual meeting World Mariculture Society, San Jose, Costa Rica, January 9-13, 1977, pp. 557-565.

Hand, R.E., Nell, J.A., Maguire, G.B., 1998. Studies on triploid oysters in Australia. X. growth and mortality of diploid and triploid Sydney rock oysters Saccostrea commercialis (Iredale and Roughley). J Shellfish Res. 17 (4), 1115-1127.

Héral, M., 1991. Approches de la capacité trophique des écosystèmes conchylicoles : synthèse bibliographique. ICES mar. Sci. Symp. 192, 48-62.

Héral, M., Deslous-Paoli, J.M., 1991. Oyster culture in European countries. In : Estuarine and Marine bivalve mollusk culture. Menzel W. (ed.), CRC Press, Boca Raton, pp. 153-190.

Hershberger, W.K., Perdue, J.A., Beattie, J.H., 1984. Genetic selection and systematic breeding in pacific oyster culture. Aquaculture 39, 237-245.

Imai, T., Mori, K., Sugawara, Y., Tamate, H., Oizumi, J., Itikawa, O., 1968. Studies on the Mass Mortality of Oysters in Matsushima Bay VII. Tohoku J. Agricult. Res. 19 (4), 250-265.

Jarayabhand, P., Newkirk, G.F., 1989. Effects of intraspecific competition on growth of the European oyster, Ostrea edulis Linnaeus, 1750. J. Shellfish Res. 8 (2), 359-365.

Joseph, M., Madhyastha, M.N., 1984. Annual reproductive cycle and sexuality of the oyster Crassostrea madrasensis (Preston). Aquaculture 40, 223-231.

Koganezawa, A., 1975. Present status of studies on the mass mortality of cultured oysters in Japan and its prevention. In: Proceedings of the Third U.S.-Japan Meeting on Aquaculture. Tokyo, Japan, October 15-16, 1974, pp. 29-34.

Lambert, C., Soudant, P., Choquet, G., Paillard, C., Frouel S., Dégremont, L., Delaporte, M., Moal, J., Boudry, P., Soletchnik, P., Ropert, M., Bédier, E., Renault, T., Gagnières, B., Huvet, A., Samain, J-F., 2003. Immunological status of selected Crassostrea gigas families and descendants, reared in different environmental conditions. J. Shellfish Res. 22(1), 339 (abstract).

Langdon, C., Evans, F., Jacobson, D., and Blouin, M. (2003).Yields of cultured Pacific oysters Crassostrea gigas Thunberg improved after one generation of selection. Aquaculture 220: 227-244.

Le Roux, F., Gay, M., Lambert, C., Waechter, M., Poubalanne, S., Chollet, B., Nicolas, J.L., Berthe, F., 2002. Comparative analysis of Vibrio splendidus-related strains isolated during Crassostrea gigas mortality events. Aquat. Living Resour. 15, 251-258.

Littell, R.C., Stroup, W.W., Freund, R.J., 2002. SAS ${ }^{\circledR}$ for Linear Models, Fourth Edition. Cary, NC : SAS Institute Inc. 466 pp.

Mann, R, Burreson E.M., Baker, P.K., 1991. The decline of the virginia oyster fishery in Chesapeake Bay: considerations for introduction of a non-endemic species, Crassostrea gigas (Thunberg, 1793). J. Shellfish Res. 10(2), 379-388.

Maurer, D., Comps, M., 1986. Mortalités estivales de l'huître Crassostrea gigas dans le bassin d'Arcachon : facteurs du milieu, aspects biochimiques et histologiques. In : Pathology in Marine Aquaculture, Vivarès, C.P., Bonami, J.R. and Jaspers, E. (Ed). European Aquaculture Society, Special Publication Nº 9, Bredene, Belgium, pp. 29-41.

Maurer, D., Comps M., His, E., 1986. Caractéristiques des mortalités estivales de l'huître Crassostrea gigas dans le bassin d'Arcachon. Haliotis 15, 309-317.

Mitchell, I.M., Crawford, C.M., Rushton, M.J., 2000. Flat oyster (Ostrea angasi) growth and survival rates at Georges Bay, Tasmansia (Australia). Aquaculture 191, 309-321.

Moal, J., Bédier, E., Fleury, P.G., Langlade, A., LeCoguic, Y., Dégremont, L., Boudry, P., Le Coz, J.R., Pouvreau, S., Enriquez-Diaz, M., Lambert, C., Soudant, P., Samain, J.F., 2003. 
Genetic variability in reproduction and summer mortality in Crassostrea gigas. J. Shellfish Res. 22 (1), 345.

Morton, B., 1990. Life cycle and sexual strategy of Saccostrea cucullata (Bivalvia, Ostreidae) from a Hong-Kong Mangrove. Amer. Malacol. Bull. 8 (1), 1-8.

Nell, J.A., Sheridan, A.K., Smith, I. R., 1996. Progress in a Sydney rock oyster, Saccostrea commercialis (Iredale and Roughley), breeding program. Aquaculture, 144, 295-302.

Nell, J.A., Smith, I. R., Sheridan, A.K., 1999. Third generation evaluation of Sydney rock oyster Saccostrea commercialis (Iredale and Roughley) breeding lines. Aquaculture, 170, 195-203.

Neter, J., Wasserman, W., Kutner, M. H., 1985. Applied linear statistical models: Regression, analysis of covariance and experimental designs. R.D. Irwin, Illinois: 1127 p.

Perdue, J.A., Beattie, J.H., Chew, K.K., 1981. Some relationships between gametogenic cycle and summer mortality phenomenon in the Pacific oyster (Crassostrea gigas) in Washington State. J. Shellfish Res. 1 (1), 9-16.

SAS Institute Inc., 1989. SAS/STAT ${ }^{\circledR}$ User's Guide, Version 6, Fourth Edition, Volume 2, Cary, NC : SAS Institute Inc.: 846 p.

SAS Institute Inc., 1995. Basis statistics using SAS/STAT ${ }^{\circledR}$, software course notes. Cary, NC : SAS Institute Inc.: 720 p.

Shafee, M., Sabatie, M., 1986. Croissance et mortalité des huîtres dans la lagune de Oualidia (Maroc). Aquaculture 53, 201-214.

Sheridan, A.K., 1997. Genetic improvement of oyster production-a critique. Aquaculture 153, 165-179.

Sindermann, C.J., 1976. Oyster mortalities and their Control. In : Pillay T.V.R. and Dill W.M., eds. Advances in Aquaculture. Fishing News Brooks Farnham, England, pp. 349-361.

Soletchnik, P., Le Moine, O., Faury, N., Razet, D., Geairon, P., Goulletquer, P., 1999. Mortalité de l'huître Crassostrea gigas dans le bassin due Marennes-Oléron : étude de la variabilité spatiale de son environnement et de sa biologie par un système d'informations géographiques (SIG). Aquat. Living Resour. 12 (2), 131-143.

Soletchnik, P., Huvet, A., Le Moine, O., Razet D., Geairon, P., Faury N., Goulletquer, P., Boudry, P., 2002. A comparative field study of growth, survival and reproduction of Crassostrea gigas, C-angulata and their hybrids. Aquat. Living Resour. 15 (4), 243-250.

Soletchnik, P., Ropert, M., Huvet, A., Moal, J., Dégremont, L., Bédier, E., Bouget, J.F., Dubois, B., Martin, J.L., Enriquez-Diaz, M., Faury, N., Le Moine, O., Renault, T., Gagnaire, B., Samain, J.F., 2003. Characterization of summer mortalities of C. gigas. in France relation to environmental parameters. J. Shellfish Res., 22(1), 354.

Sparks, A.K., Chew, K.K., 1959. Preliminary report on growth and survival of the Pacific oyster in Washington waters. Proceed. Natl. Shellfish Assoc., 125-132.

Takeuchi, T., Takemoto, Y., Matsubara, T., 1960. Haematological study of bacterial affected oysters. Rep. Hiroshima Prefect. Fish. Exp. Stn. 22(1), 1-7. Transl. U.S. Joint Publ. Res. Serv. For Transl. Program. Bur. Comm. Fish, Milford, Conn.(1965).

Tamate, H., Numachi, K.I., Mori, K., Itikawa, O., Imai, T., 1965. Studies on the mass mortality of the oyster in Matsushima Bay VI. Pathological studies. Bull. Tohoku Reg. Fish. Res. Lab. 25, 89-104.

Ventilla, R.F., 1984. Recent developments in the Japanese oyster culture industry. Advances in Marine Biology 21, 2-54.

Waechter, M., Le Roux, F., Nicolas, JL., Marissal, E., Berthe, F., 2002. Caractérisation de bactéries pathogènes de naissain d'huître creuse Crassostrea gigas. C.R. Biologies 325, 231238.

Zouros, E., Singh, S.M., Miles, H.E., 1980. Growth rate in oyster: an overdominant phenotype and its possible explanations. Evolution 34 (5), 356-367. 
Table 1: Analyses of variance : mean squares and $\mathrm{P}$ value for survival and yield, and variance components for the three sampling dates.

\begin{tabular}{|c|c|c|c|c|c|c|c|c|}
\hline \multirow[b]{2}{*}{$\begin{array}{l}\text { Sampling } \\
\text { dates }\end{array}$} & \multirow[b]{2}{*}{ Source } & \multirow[b]{2}{*}{ df } & \multicolumn{3}{|l|}{ Survival } & \multicolumn{3}{|l|}{ Yield } \\
\hline & & & $\begin{array}{l}\text { Mean } \\
\text { squares }\end{array}$ & $\mathrm{P}$ value & $\begin{array}{l}\text { Variance } \\
\text { components } \\
\text { (\%) }\end{array}$ & $\begin{array}{l}\text { Mean } \\
\text { squares }\end{array}$ & $\mathrm{P}$ value & $\begin{array}{l}\text { Variance } \\
\text { components } \\
(\%)\end{array}$ \\
\hline \multirow[t]{7}{*}{ P1 } & Group & 2 & 0.71 & 0.0116 & 10.1 & 87.01 & 0.0001 & 16.6 \\
\hline & Family (group) & 41 & 0.14 & 0.0001 & 33.9 & 7.79 & 0.0001 & 24.0 \\
\hline & Site & 2 & 0.27 & 0.0001 & 3.5 & 52.29 & 0.0001 & 9.0 \\
\hline & Replicate(family group) & 88 & 0.01 & 0.6833 & 0.0 & 0.78 & 0.7016 & 0.0 \\
\hline & Group x site & 4 & 0.10 & 0.0088 & 4.4 & 18.37 & 0.0001 & 13.0 \\
\hline & Site x family(group) & 82 & 0.03 & 0.0001 & 12.8 & 1.57 & 0.0005 & 8.5 \\
\hline & Error & 176 & 0.01 & & 35.2 & 0.87 & & 29.0 \\
\hline \multirow[t]{7}{*}{$\mathrm{P} 2$} & Group & 2 & 1.09 & 0.0423 & 7.2 & 25.53 & 0.1677 & 0.0 \\
\hline & Family (group) & 41 & 0.32 & 0.0001 & 45.1 & 13.68 & 0.0001 & 29.8 \\
\hline & Site & 2 & 1.15 & 0.0001 & 11.0 & 196.07 & 0.0001 & 29.8 \\
\hline & Replicate(family group) & 88 & 0.02 & 0.1316 & 1.5 & 1.00 & 0.0382 & 2.1 \\
\hline & Group x site & 4 & 0.16 & 0.0029 & 4.2 & 30.34 & 0.0001 & 13.2 \\
\hline & Site x family(group) & 82 & 0.04 & 0.0001 & 11.5 & 1.79 & 0.0001 & 8.3 \\
\hline & Error & 176 & 0.01 & & 19.6 & 0.72 & & 16.8 \\
\hline \multirow[t]{7}{*}{ P3 } & Group & 2 & 0.05 & 0.8678 & 0.0 & 142.70 & 0.0003 & 11.0 \\
\hline & Family (group) & 41 & 0.36 & 0.0001 & 46.4 & 14.11 & 0.0001 & 15.1 \\
\hline & Site & 2 & 1.99 & 0.0001 & 20.8 & 666.33 & 0.0001 & 57.3 \\
\hline & Replicate(family group) & 88 & 0.01 & 0.3817 & 0.3 & 1.03 & 0.2783 & 0.4 \\
\hline & Group x site & 4 & 0.06 & 0.2366 & 0.4 & 4.80 & 0.0850 & 0.6 \\
\hline & Site x family(group) & 82 & 0.04 & 0.0001 & 13.7 & 2.26 & 0.0001 & 5.1 \\
\hline & Error & $175 / 173$ & 0.01 & & 18.4 & 0.92 & & 10.4 \\
\hline
\end{tabular}


Table 2: Mean and standard deviation of survival per group in the three sites for the three sampling dates. The tests of significance are as follows: (a) differences among full-sib families within each group, (b) differences among sites, (c) differences among groups.

\begin{tabular}{|c|c|c|c|c|c|}
\hline Site & $\mathrm{P}$ & Group 1 & Group 2 & Group 3 & All Groups \\
\hline \multirow[t]{3}{*}{ Ronce } & P1 & $97.5 \pm 6.8 / \mathrm{a}^{* *}$ & $91.8 \pm 10.9 / \mathrm{a}^{* *}$ & $88.5 \pm 17.0 / \mathrm{a}^{* *}$ & $92.5 \pm 12.7 / \mathrm{c}^{*}$ \\
\hline & P2 & $97.4 \pm 3.2 / \mathrm{a}^{\mathrm{ns}}$ & $85.7 \pm 18.5 / a^{* *}$ & $81.7 \pm 23.0 / \mathrm{a}^{* *}$ & $88.1 \pm 18.2 / \mathrm{C}^{* *}$ \\
\hline & P3 & $88.7 \pm 14.2 / \mathrm{a}^{* *}$ & $83.1 \pm 18.1 / \mathrm{a}^{* *}$ & $81.3 \pm 21.3 / \mathrm{a}^{* *}$ & $84.3 \pm 18.0 / c^{\mathrm{ns}}$ \\
\hline \multirow[t]{3}{*}{ Rivière d'Auray } & $\mathrm{P} 1$ & $97.8 \pm 5.5 / \mathrm{a}^{\mathrm{ns}}$ & $89.4 \pm 15.8 / \mathrm{a}^{* *}$ & $94.8 \pm 6.0 / \mathrm{a}^{\mathrm{ns}}$ & $93.9 \pm 10.7 / c^{* *}$ \\
\hline & $\mathrm{P} 2$ & $89.1 \pm 12.3 / \mathrm{a}^{* *}$ & $87.2 \pm 18.4 / \mathrm{a}^{* *}$ & $77.8 \pm 23.5 / \mathrm{a}^{* *}$ & $84.6 \pm 19.0 / c^{\mathrm{ns}}$ \\
\hline & P3 & $75.6 \pm 21.1 / \mathrm{a}^{* *}$ & $76.5 \pm 22.1 / \mathrm{a}^{* *}$ & $74.4 \pm 26.5 / \mathrm{a}^{* *}$ & $75.5 \pm 22.9 / \mathrm{c}^{\mathrm{ns}}$ \\
\hline \multirow[t]{3}{*}{ Baie des Veys } & P1 & $99.3 \pm 0.6 / \mathrm{a}^{\mathrm{ns}}$ & $96.5 \pm 5.1 / a^{* *}$ & $98.4 \pm 1.8 \quad / \mathrm{a}^{*}$ & $98.0 \pm 3.3 / \mathrm{c}^{* *}$ \\
\hline & $\mathrm{P} 2$ & $98.9 \pm 1.0 \quad / \mathrm{a}^{\mathrm{ns}}$ & $95.6 \pm 3.3 / \mathrm{a}^{* *}$ & $93.7 \pm 14.9 / \mathrm{a}^{* *}$ & $96.0 \pm 9.0 \quad / \mathrm{c}^{*}$ \\
\hline & P3 & $94.4 \pm 2.7 \quad / \mathrm{a}^{\mathrm{ns}}$ & $93.2 \pm 4.8 \quad / \mathrm{a}^{\mathrm{ns}}$ & $93.1 \pm 11.6 / \mathrm{a}^{* *}$ & $93.6 \pm 7.3 \quad / c^{\mathrm{ns}}$ \\
\hline \multirow[t]{3}{*}{ All sites } & P1 & $98.2 \pm 5.0 / b^{\mathrm{ns}}$ & $92.6 \pm 11.6 / b^{* *}$ & $93.9 \pm 11.0 / b^{* *}$ & $94.8 \pm 10.0 \mathrm{~b}^{* *} / \mathrm{c}^{*}$ \\
\hline & P2 & $95.1 \pm 8.4 \quad / b^{* *}$ & $89.5 \pm 15.5 / b^{*}$ & $84.4 \pm 21.5 / b^{* *}$ & $89.5 \pm 16.6 \mathrm{~b}^{* *} / \mathrm{c}^{*}$ \\
\hline & P3 & $86.2 \pm 16.5 / b^{* *}$ & $84.2 \pm 17.8 / b^{* *}$ & $83.0 \pm 21.7 / b^{* *}$ & $84.4 \pm 18.7 b^{* *} / c^{n s}$ \\
\hline
\end{tabular}

$(* *: \mathrm{p}<0.01 ; *: \mathrm{p}<0.05 ;$ ns : non significant $)$ 
Table 3: Analyses of covariance : mean squares and P value for growth between P0-P2 and between P0-P3, and variance components for individual weight at P2 and P3.

\begin{tabular}{llrcc}
\hline Source & df & Mean squares & P value & $\begin{array}{l}\text { Variance } \\
\text { components } \\
\text { (\%) }\end{array}$ \\
\hline (a) P0-P2 growth & & & & $\begin{array}{c}\text { P2 individual weight } \\
\text { Group }\end{array}$ \\
Family (group) & 41 & 1.19 & 0.0 \\
Site & 2 & 12.15 & 0.0001 & 11.6 \\
Group x site & 4 & 40.96 & 0.0001 & 4.0 \\
Site x family(group) & 82 & 9.64 & 0.0001 & 3.3 \\
Error & 33558 & 0.31 & 0.0005 & 3.9 \\
& & & & 77.1 \\
(b) P0-P3 growth & & & & P3 Individual weight \\
Group & 2 & 12.93 & 0.0001 & 22.5 \\
Family (group) & 41 & 7.51 & 0.0001 & 4.5 \\
Site & 2 & 365.38 & 0.0001 & 25.3 \\
Group x site & 4 & 20.18 & 0.0001 & 5.2 \\
Site x family(group) & 82 & 0.96 & 0.5887 & 1.5 \\
Error & 32673 & 0.30 & & 41.0 \\
& & & & \\
\hline
\end{tabular}


Table 4: Mean and standard deviation of individual weight (g) observed per group for date of placement in the field (P0), for the second (P2) and the final sampling (P3). The tests of significance are as follows: (a) differences among full-sib families within each group, (b) differences among sites, (c) differences among groups.

\begin{tabular}{llcccc}
\hline Site & P & Group 1 & Group 2 & Group 3 & All groups \\
\hline Bouin & P0 & $1.67 \pm 0.47 / \mathrm{a}^{* *}$ & $1.70 \pm 0.28 / \mathrm{a}^{* *}$ & $1.65 \pm 0.35 / \mathrm{a}^{* *}$ & $1.67 \pm 0.36 / \mathrm{a}^{\mathrm{ns}}$ \\
Ronce & P2 & $4.73 \pm 0.81 / \mathrm{a}^{* *}$ & $4.70 \pm 0.77 / \mathrm{a}^{* *}$ & $4.35 \pm 0.85 / \mathrm{a}^{* *}$ & $4.59 \pm 0.81 / \mathrm{a}^{\mathrm{ns}}$ \\
& P3 & $16.11 \pm 2.32 / \mathrm{a}^{* *}$ & $13.44 \pm 1.73 / \mathrm{a}^{* *}$ & $6.67 \pm 1.07 / \mathrm{a}^{* *}$ & $11.98 \pm 4.37 / \mathrm{a}^{*}$ \\
Rivière d’Auray & P2 & $3.80 \pm 0.73 / \mathrm{a}^{* *}$ & $4.00 \pm 0.72 / \mathrm{a}^{* *}$ & $3.79 \pm 0.82 / \mathrm{a}^{* *}$ & $3.86 \pm 0.75 / \mathrm{a}^{\mathrm{ns}}$ \\
& P3 & $11.17 \pm 2.09 / \mathrm{a}^{* *}$ & $9.22 \pm 1.15 / \mathrm{a}^{\mathrm{ns}}$ & $5.07 \pm 0.80 / \mathrm{a}^{* *}$ & $8.42 \pm 2.93 / \mathrm{a}^{\mathrm{ns}}$ \\
Baie des Veys & P2 & $4.48 \pm 0.86 / \mathrm{a}^{*}$ & $4.04 \pm 0.68 / \mathrm{a}^{* *}$ & $5.18 \pm 1.18 / \mathrm{a}^{* *}$ & $4.54 \pm 0.91 / \mathrm{a}^{* *}$ \\
& P3 & $19.63 \pm 3.07 / \mathrm{a}^{* *}$ & $16.31 \pm 1.18 / \mathrm{a}^{*}$ & $9.47 \pm 1.41 / \mathrm{a}^{*}$ & $15.03 \pm 4.71 / \mathrm{a}^{* *}$ \\
All sites & P2 & $4.33 \pm 0.88 / \mathrm{b}^{* *}$ & $4.25 \pm 0.78 / \mathrm{b}^{* *}$ & $4.44 \pm 1.10 / \mathrm{b}^{* *}$ & $4.34 \pm 0.93 \mathrm{~b}^{* *} / \mathrm{c}^{\mathrm{ns}}$ \\
& P3 & $15.64 \pm 4.29 / \mathrm{b}^{* *}$ & $12.99 \pm 3.24 / \mathrm{b}^{* *}$ & $7.07 \pm 2.14 / \mathrm{b}^{* *}$ & $11.81 \pm 4.87 \mathrm{~b}^{* *} / \mathrm{c}^{* *}$ \\
\hline
\end{tabular}

$(* *: \mathrm{p}<0.01 ; *: \mathrm{p}<0.05 ;$ ns : non significant) 
Table 5: Mean and standard deviation of daily yield (\% per day) observed per group in the three sites and for the three sampling dates. The tests of significance are as follows: (a) differences among full-sib families within each group, (b) differences among sites, (c) differences among groups.

\begin{tabular}{lccccc}
\hline Site & P & Group 1 & Group 2 & Group 3 & All groups \\
\hline Ronce & P1 & $2.67 \pm 0.81 / \mathrm{a}^{* *}$ & $1.77 \pm 1.25 / \mathrm{a}^{* *}$ & $1.52 \pm 1.89 / \mathrm{a}^{* *}$ & $1.97 \pm 1.45 / \mathrm{c}^{\mathrm{ns}}$ \\
& P2 & $4.54 \pm 0.63 / \mathrm{a}^{\mathrm{ns}}$ & $3.55 \pm 1.73 / \mathrm{a}^{* *}$ & $2.80 \pm 2.01 / \mathrm{a}^{* *}$ & $3.61 \pm 1.71 / \mathrm{c}^{*}$ \\
& P3 & $6.47 \pm 1.83 / \mathrm{a}^{* *}$ & $5.47 \pm 1.59 / \mathrm{a}^{* *}$ & $3.64 \pm 1.70 / \mathrm{a}^{* *}$ & $5.16 \pm 2.04 / \mathrm{c}^{* *}$ \\
Rivière d'Auray & P1 & $2.72 \pm 0.45 / \mathrm{a}^{\mathrm{ns}}$ & $0.95 \pm 1.61 / \mathrm{a}^{* *}$ & $2.07 \pm 0.85 / \mathrm{a}^{\mathrm{ns}}$ & $1.89 \pm 1.30 / \mathrm{c}^{* *}$ \\
& P2 & $2.89 \pm 1.10 / \mathrm{a}^{* *}$ & $2.61 \pm 1.44 / \mathrm{a}^{* *}$ & $1.51 \pm 1.58 / \mathrm{a}^{* *}$ & $2.32 \pm 1.52 / \mathrm{c}^{*}$ \\
Baie des Veys & P1 & $3.70 \pm 0.52 / \mathrm{a}^{* *}$ & $1.56 \pm 0.73 / \mathrm{a}^{* *}$ & $3.85 \pm 0.82 / \mathrm{a}^{\mathrm{ns}}$ & $3.02 \pm 1.26 / \mathrm{c}^{* *}$ \\
& P2 & $4.85 \pm 0.71 / \mathrm{a}^{\mathrm{ns}}$ & $3.93 \pm 0.49 / \mathrm{a}^{* *}$ & $5.54 \pm 1.56 / \mathrm{a}^{* *}$ & $4.77 \pm 1.26 / \mathrm{c}^{* *}$ \\
All sites & P3 & $8.04 \pm 1.54 / \mathrm{a}^{* *}$ & $7.46 \pm 0.90 / \mathrm{a}^{\mathrm{ns}}$ & $6.38 \pm 1.25 / \mathrm{a}^{* *}$ & $7.28 \pm 1.40 / \mathrm{c}^{* *}$ \\
& P1 & $3.03 \pm 0.76 / \mathrm{b}^{* *}$ & $1.43 \pm 0.27 / \mathrm{b}^{* *}$ & $2.48 \pm 1.61 / \mathrm{b}^{* *}$ & $2.30 \pm 1.42 \mathrm{~b} \mathrm{~b}^{* *} / \mathrm{c}^{* *}$ \\
& P2 & $4.09 \pm 1.20 / \mathrm{b}^{* *}$ & $3.36 \pm 1.41 / \mathrm{b}^{* *}$ & $3.28 \pm 1.44 / \mathrm{b}^{* *}$ & $3.57 \pm 1.80 \mathrm{~b}^{* *} / \mathrm{c}^{\mathrm{ns}}$ \\
& P3 & $6.02 \pm 2.48 / \mathrm{b}^{* *}$ & $5.30 \pm 2.22 / \mathrm{b}^{* *}$ & $3.95 \pm 2.36 / \mathrm{b}^{* *}$ & $5.07 \pm 2.49 \mathrm{~b} \mathrm{~b}^{* *} / \mathrm{c}^{* *}$ \\
\hline
\end{tabular}


Figure 1: Map showing location of Ronce, Rivière d'Auray and Baie des Veys in France.

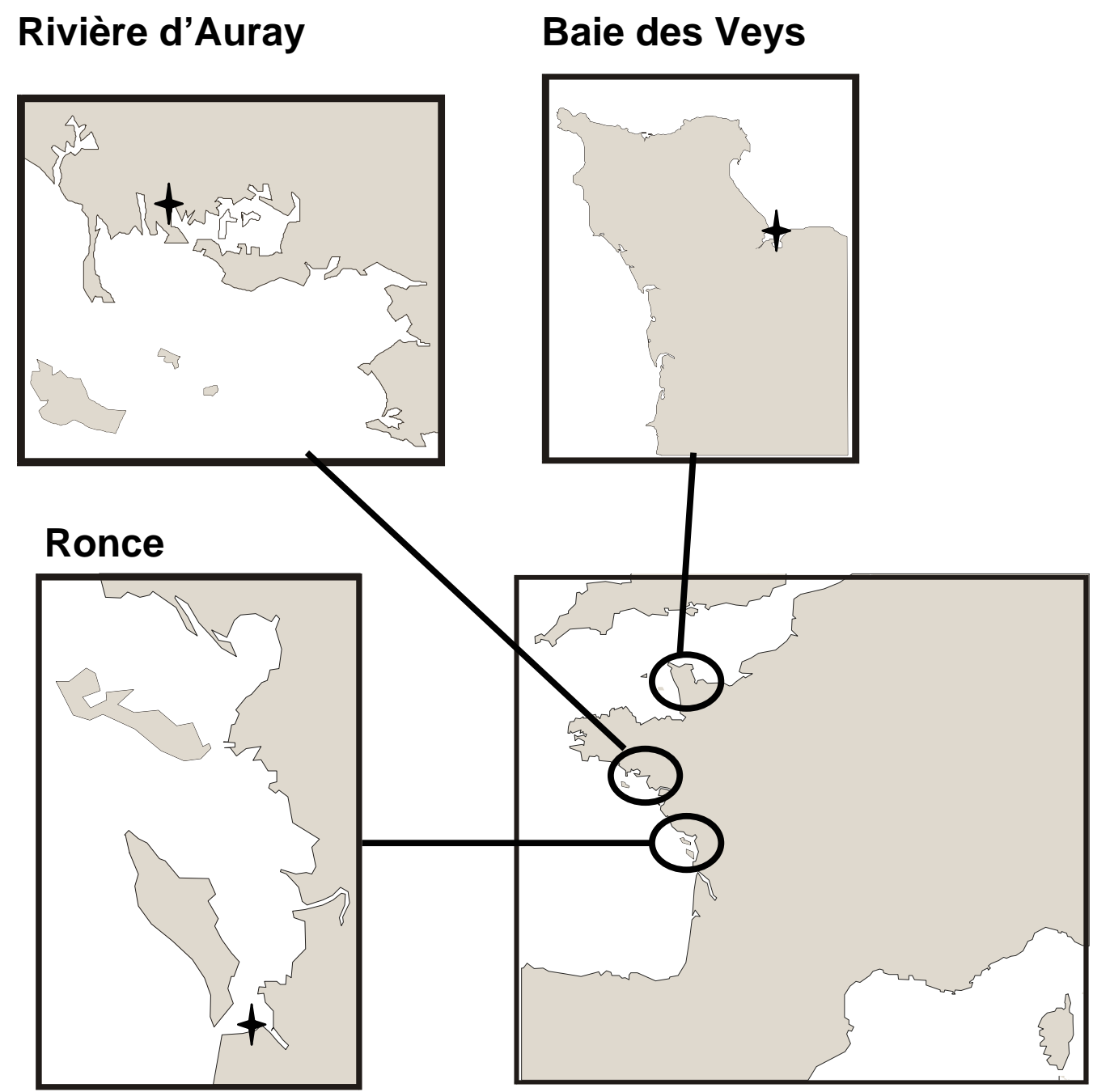


Figure 2: Evolution of temperature in the three sites during the growout experiment. $(\mathrm{RA}=$ Rivière d'Auray and BDV = Baie des Veys). Vertical bars represent placement date (P0) or sampling dates (P1, P2, P3) for each group (G).

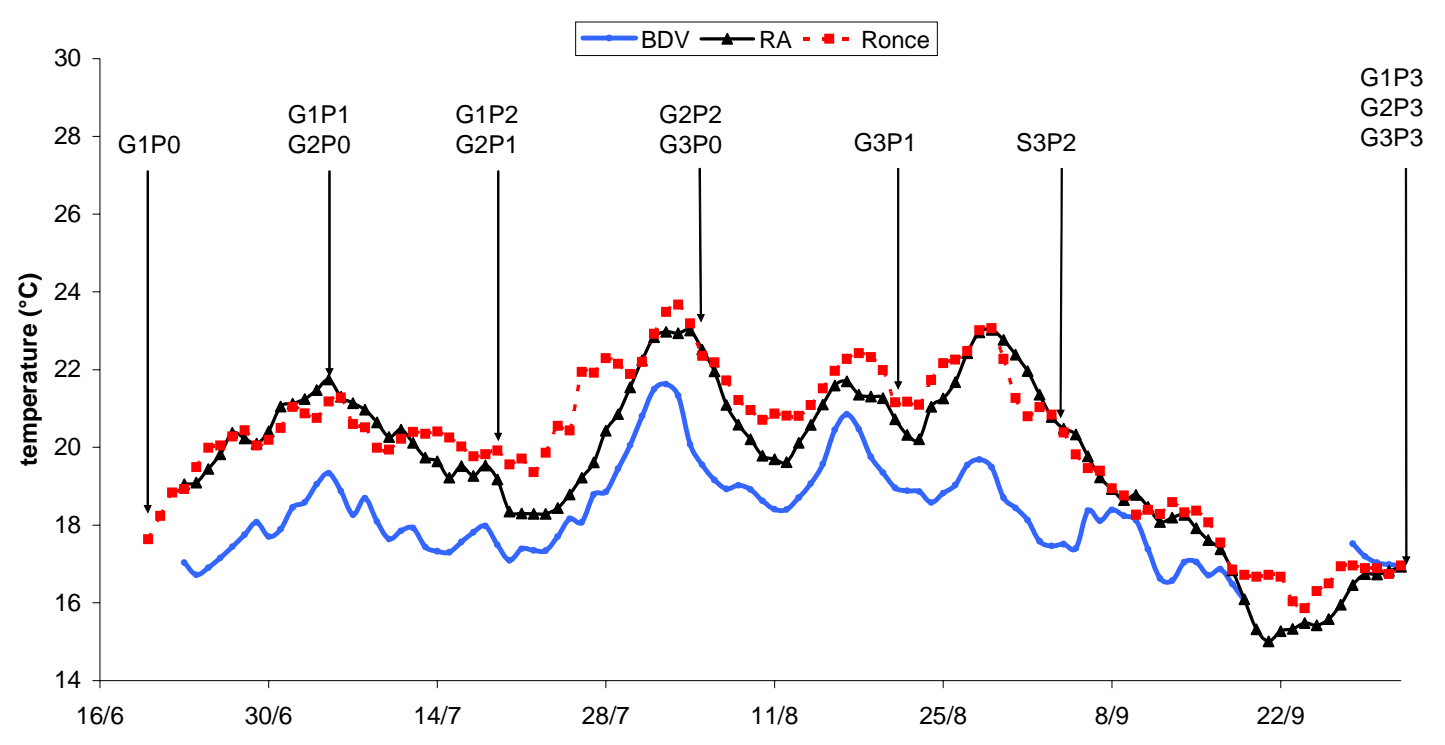


Figure 3: Growth and survival contributions for the explanation of the daily yield for each group and each site, and for overall groups in the 3 sites in October 2001 (RA = Rivière d'Auray and BDV = Baie des Veys).

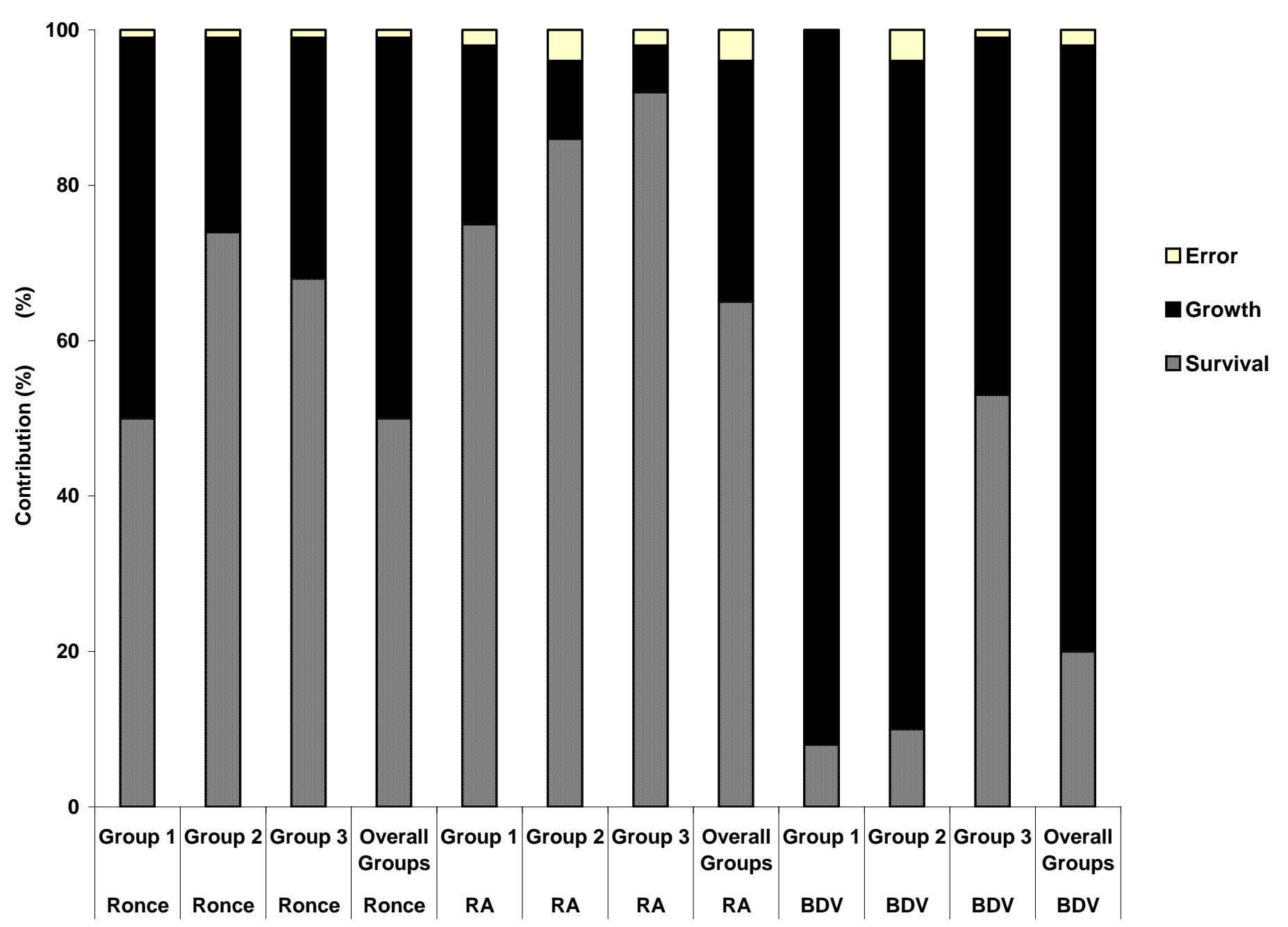

